\title{
Central Pressure and Biomarker Responses to Renin Inhibition with Hydrochlorothiazide and Ramipril in Obese Hypertensives: The ATTAIN Study
}

\author{
Adam Whaley-Connell $^{b, d, e}$ Das Purkayastha $^{f}$ Anthony Yadao $^{f}$ \\ James R. Sowers ${ }^{\text {a-e }}$ \\ aDivision of Endocrinology, Diabetes and Metabolism, at ${ }^{\mathrm{b}}$ Department of Internal Medicine, \\ 'Department of Medical Pharmacology and Physiology, University of Missouri-Columbia School of \\ Medicine, dDiabetes and Cardiovascular Center, and ${ }^{\mathrm{e}}$ Harry S. Truman VA Medical Center, \\ Columbia, Mo., and f Novartis Pharmaceuticals Corporation, East Hanover, N.J., USA
}

\section{Key Words}

Aliskiren $\cdot$ Hydrochlorothiazide $\cdot$ Obesity $\cdot$ Plasma renin activity $\cdot$ Ramipril $\cdot$ Stage 2 hypertension

\begin{abstract}
Background/Aims: In obese, hypertensive subjects, the renin-angiotensin system (RAS) is enhanced and natriuresis impaired, suggesting a role for combination RAS blockade with diuretics. Data suggest that renin inhibition may attenuate diuretic-induced RAS activation and oxidative stress. Methods: In this 8-week, double-blind study of 386 obese individuals (mean body mass index: 35.3 ) with stage 2 hypertension (mean age: 54.9 years; mean sitting systolic blood pressure, SBP: $\geq 160$ but $<200 \mathrm{~mm} \mathrm{Hg}$ ), we compared the efficacy of aliskiren + hydrochlorothiazide (HCTZ) in reducing blood pressure (BP), plasma renin activity (PRA), and a urinary marker of oxidative stress to ramipril. Subjects were randomized to aliskiren/HCTZ 150/12.5 mg or ramipril $5 \mathrm{mg}$ for 1 week, and after the 1st week force titrated to aliskiren/HCTZ 300/25 mg or ramipril $10 \mathrm{mg}$ for 7 weeks. Results: After 8 weeks, aliskiren/HCTZ provided greater reductions in office BP than ramipril (-28.1/-10.1 vs. $-16.6 /-3.6 \mathrm{~mm} \mathrm{Hg}, \mathrm{p}<0.0001)$ as well as 24 -hour ambulatory and central pressure measures. Aliskiren/HCTZ also lowered PRA $(-45$ vs. $+83 \%)$ and the urinary $\mathrm{F} 2$-isoprostane/creatinine ratio $(-18 \mathrm{vs} .+7 \%)$ to a greater extent than ramipril. Adverse events (AEs) were similar in the two groups (35.8\% with aliskiren/HCTZ vs. $37.3 \%$ on
\end{abstract}

This study was presented in part at the 25th Annual Scientific Meeting and Exposition of the American Society of Hypertension (May 1-4, 2010, New York, N.Y., USA). 


\section{CardioRenal \\ Medicine}

\begin{tabular}{l|l}
\hline Cardiorenal Med 2011;1:53-66 \\
\hline $\begin{array}{l}\text { DOI: 10.1159/000322864 } \\
\text { Published online: January 17, } 2011\end{array}$ & $\begin{array}{l}\text { @ } 2011 \text { S. Karger AG, Basel } \\
\text { www.karger.com/crm }\end{array}$ \\
\hline
\end{tabular}

Whaley-Connell et al.: Renin Inhibition in Obese Hypertensives

ramipril reporting at least one $\mathrm{AE}$ ). Conclusions: Our findings suggest that the aliskiren/HCTZ combination reduced BP, PRA, and isoprostanes to a greater extent than did ramipril in obese patients with stage 2 hypertension.

Copyright $\odot 2011$ S. Karger AG, Basel

\section{Introduction}

In the United States, $>70 \%$ of adults with hypertension are overweight or obese $[1,2]$, and $<20 \%$ of them have their blood pressure (BP) controlled to $<140 / 90 \mathrm{~mm} \mathrm{Hg}$ [3]. Although the mechanisms by which obesity raises BP are not completely understood, increased renal sodium reabsorption, impaired pressure natriuresis, and volume expansion appear to play important roles. Several mechanisms have been suggested to contribute to the altered kidney function and hypertension in obesity, including activation of the sympathetic nervous system [4] and the renin-angiotensin system (RAS) [5, 6]. Obese subjects with hypertension often display increases in plasma renin activity (PRA), angiotensin II (Ang II), and aldosterone levels $[5,6]$. Thus, obesity is associated with inappropriate RAS activation that, in turn, contributes to oxidative stress and consequent vascular volume expansion, increased salt sensitivity, and impaired vasodilation.

Given the close association of obesity-related hypertension and RAS-mediated oxidative stress and impaired renal pressure natriuresis/volume expansion, diuretics are important components of a hypertensive therapy regimen in overweight/obese persons [7]. However, diuretics increase PRA and measures of inflammation [8]. RAS inhibition blocks the rise in renin released from the kidney that occurs in response to sodium depletion and thereby enhances the BP-lowering effects of diuretic treatment $[9,10]$. Aliskiren is the first direct renin inhibitor to decrease angiotensinogen, PRA, Ang II, and aldosterone levels, all of which are increased in obese individuals with hypertension [10].

Aliskiren has previously been studied in obese patients with hypertension (mostly stage 1) uncontrolled on 25-mg hydrochlorothiazide (HCTZ) monotherapy [10]. Comparison groups were given an angiotensin receptor blocker (ARB, irbesartan), a dihydropyridine calcium channel blocker (amlodipine), or placebo added to $25 \mathrm{mg} \mathrm{HCTZ}$ in a dose escalation design. The aliskiren/thiazide combination had a tolerability profile similar to placebo/thiazide, and provided BP reductions similar to those in the ARB and calcium channel blocker groups [10]. In the TROPHY study (Treatment in Obese Patients with Hypertension), which compared the angiotensin-converting enzyme inhibitor (ACEI) lisinopril to HCTZ, there were similar reductions in BP with both agents after 12 weeks of treatment [11]. Thereby, comparative data on ACEI or the aliskiren/HCTZ combination are lacking in obese stage 2 hypertensives.

Measurement of systolic BP (SBP) in the brachial artery in certain at-risk populations such as the obese, hypertensive individual can provide an inaccurate measure of SBP. The relationship between peripheral brachial SBP and central SBP varies among individuals, depending on the vascular stiffness and the shape of the pressure waveform. The inaccuracy of brachial measurement is largely due to distortion of the BP waveform (and systolic pressure) from wave reflections from the periphery. Recent data suggest a differential effect of various antihypertensive agents based on brachial artery recordings: their effect on central aortic SBP may be over- or underestimated [12].

Thereby, in the ATTAIN study (Aliskiren/HCTZ vs. Ramipril in Obese Patients with Stage 2 Hypertension), we compared the antihypertensive efficacy and safety of the initial single-pill combination of aliskiren/HCTZ $(300 / 25 \mathrm{mg})$ with ramipril $(10 \mathrm{mg})$ in obese patients with stage 2 hypertension and measured brachial, central, and ambulatory levels of SBP as well as RAS activity and oxidative stress. 


\section{CardioRenal \\ Medicine}

\begin{tabular}{l|l}
\hline Cardiorenal Med 2011;1:53-66 \\
\hline DOI: 10.1159/000322864 & $\begin{array}{l}\text { @ 2 2011 S. Karger AG, Basel } \\
\text { www.karger.com/crm }\end{array}$ \\
Published online: January 17, 2011 &
\end{tabular}

Whaley-Connell et al.: Renin Inhibition in Obese Hypertensives

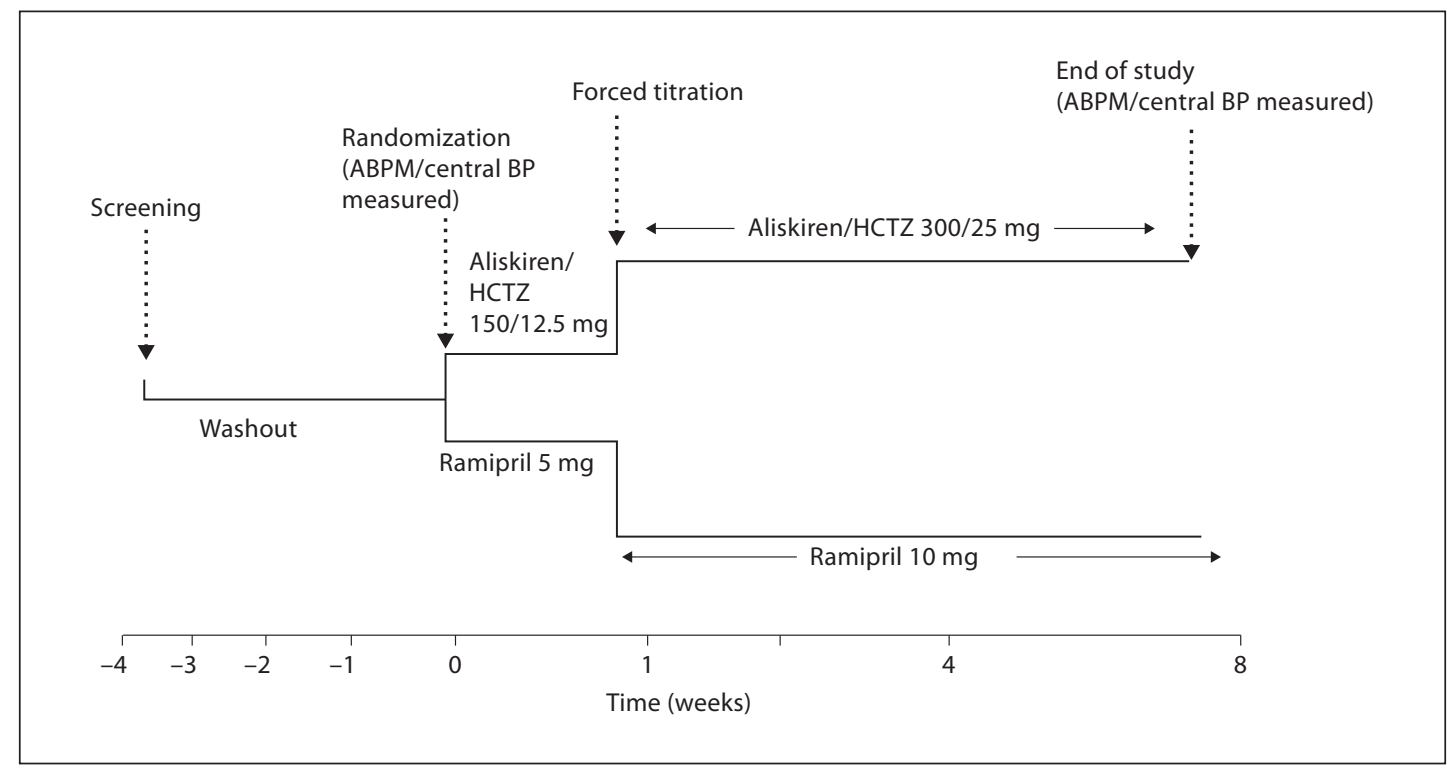

Fig. 1. Study design.

\section{Methods}

\section{Patients}

Eligible patients were men and women aged 18 years or older with a body mass index (BMI) between 30 and 45 , and mean sitting SBP $(\mathrm{msSBP}) \geq 160$ and $<200 \mathrm{~mm} \mathrm{Hg}$. Patients with $\mathrm{msSBP}>200 \mathrm{~mm} \mathrm{Hg}$ or mean sitting diastolic $\mathrm{BP}(\mathrm{msDBP}) \geq 110 \mathrm{~mm} \mathrm{Hg}$ were excluded, as were patients with secondary hypertension, resistant hypertension unresponsive to three or more antihypertensive agents (including a diuretic), patients with type 1 or 2 diabetes, a history of myocardial infarction, heart failure, cerebrovascular accident, transient ischemic cerebral attack, coronary bypass surgery, or any percutaneous coronary intervention within the last 12 months. This study was conducted in accordance with the Declaration of Helsinki, and the study protocol was approved by the Institutional Review Board at each site. All participants provided written informed consent.

\section{Study Design}

This was an 8-week, prospective, multicenter, randomized, double-blind, active-control, parallelgroup study in obese patients (BMI > 30) conducted in 66 centers in the United States. After screening and a 1- to 4-week washout period in patients receiving antihypertensive therapy, eligible patients (msSBP $\geq 160$ and $<200 \mathrm{~mm} \mathrm{Hg}$ ) were randomized in a 1:1 ratio to either a fixed-dose combination of 150/12.5 $\mathrm{mg}$ aliskiren/HCTZ, or $5 \mathrm{mg}$ ramipril monotherapy. After the 1st week, doses were force titrated up to 300/25 mg aliskiren/HCTZ or $10 \mathrm{mg}$ ramipril for an additional 7 weeks (fig. 1).

Aliskiren/HCTZ were supplied as tablets (or matching placebo tablets) and ramipril as capsules (or matching placebo capsules). To maintain the blind status of the study, each patient was administered 2 tablets and 1 capsule per day. All of the study medications were taken with water between 7:00 and 10:00 a.m., except on the morning of clinical visits. Throughout the study, patients were not permitted to take additional drugs indicated for the treatment of hypertension.

\section{Study Objectives}

The primary objective of this study was to evaluate the superiority in the change in msSBP after 8 weeks of treatment with the aliskiren/HCTZ combination (150/12.5 and 300/25 mg) compared with that of ramipril (5 and $10 \mathrm{mg}$ ) in obese patients with stage 2 hypertension. Secondary objectives included change from baseline in msDBP in week 8 , the percentage of patients achieving BP control (defined as $\mathrm{msSBP}<140 \mathrm{~mm} \mathrm{Hg}$ and $\mathrm{msDBP}<90 \mathrm{~mm} \mathrm{Hg}$ ) and safety and tolerability. 


\section{CardioRenal Medicine}

\begin{tabular}{l|l}
\hline \multicolumn{2}{l}{ Cardiorenal Med 2011;1:53-66 } \\
\hline DOI: 10.1159/000322864 \\
Published online: January 17, 2011 & $\begin{array}{l}\text { @ 2011 S. Karger AG, Basel } \\
\text { www.karger.com/crm }\end{array}$ \\
\hline
\end{tabular}

Whaley-Connell et al.: Renin Inhibition in Obese Hypertensives

Additional variables of this study included the 24-hour mean ambulatory SBP (maSBP) and DBP $(\mathrm{maDBP})$ measured in a prespecified subgroup of randomized patients (aliskiren/HCTZ, $\mathrm{n}=45$; ramipril, $\mathrm{n}=44)$ at baseline and in week 8. Prespecifications of ambulatory BP (ABP) measures were based on the selection of prespecified centers (30 centers) and enrolled patients' willingness to participate in the study. Central arterial pressures were also assessed at baseline and in week 8 in this subgroup of patients. The following variables were also included to determine the impact of treatment on selected biomarkers, e.g. changes in PRA, aldosterone levels, and the urinary F2-isoprostane/creatinine ratio versus baseline, in a subgroup of patients after 8 weeks of treatment with initial aliskiren/HCTZ or ramipril treatment.

\section{$B P$ Measurements}

Trough sitting BP was measured ( $24 \pm 3 \mathrm{~h}$ after dosing) using a calibrated standard mercury sphygmomanometer and the recommended cuff sizes in accordance with the 2005 American Heart Association Committee report on recommendations for blood pressure measurements in humans [13]. After sitting for $5 \mathrm{~min}$, three sitting BP measurements were made at 1- to 2-min intervals, and the mean value was taken as the average BP for that visit. In the event mercury sphygmomanometers were not available as a result of regulation, an alternative calibrated method for the assessment of $\mathrm{BP}$ was used.

$\mathrm{ABP}$ measurements (ABPM) were performed by attaching the ABPM device to the non-dominant arm of the patient. A correlation was made between the ABPM device readings and measurements taken with an office mercury or aneroid sphygmomanometer. Following the correlation procedure, BP and heart rate were measured using the ABPM device every 15 min during the 24-hour monitoring period. The ABP readings had to meet satisfactory quality control criteria, which were defined as a monitoring period of at least $24 \mathrm{~h}$ with at least one valid reading per hour and at least $75 \%$ valid readings. The ABPM device was worn for at least $24 \mathrm{~h}$ before removal at the clinic. Data were processed by a central laboratory (Medifacts International, Rockville, Md., USA).

Radial artery applanation tonometry [14] was used to measure central aortic pressure in the ABPM subgroup of patients using a SphygmoCor apparatus and associated software. Radial artery tonometry was performed on the dominant arm, similar to standard sphygmomanometric measurements. The patient was asked to sit quietly for $5 \mathrm{~min}$ and radial artery applanation tonometry measurements were obtained immediately following measurement of BP by standard sphygmomanometry. These measurements were taken right after obtaining the office BPs just prior to the placement of an ABP monitor on the subject. At each time point, the subject's mean trough sitting BP by sphygmomanometry was entered into the SphygmoCor system as the calibrating BP prior to the first tonometric measurement. Three radial artery tonometric measurements were required at each visit, and data were processed through a central laboratory (AtCor Medical, Itasca, Ill., USA) [14]. The BP values taken at the time of tonometry were entered into the SphygmoCor software for calibration purposes.

\section{Biomarker Assessments}

Biomarkers were measured in plasma and urine at baseline and in week 8. Plasma renin concentration (PRC), PRA, aldosterone, and isoprostanes were collected and evaluated in all patients. The urinary albumin/creatinine ratio (UACR) was determined and evaluated in patients participating in the ABPM substudy. Metabolic parameters and biomarkers were analyzed by a central laboratory (CRL Medinet, Lenexa, Kans., USA).

Safety

Safety assessments consisted of monitoring and recording all adverse events (AEs) and serious AEs, discontinuation of treatments, regular monitoring of hematology, blood chemistry, and urinary values, regular measurement of vital signs, and the performance of physical examinations.

\section{Statistical Analysis}

A sample size of 382 patients (191 per treatment arm) completing double-blind treatment was targeted to test for superiority between the two treatment groups. This sample size provided a $85 \%$ power to detect a 4-mm Hg treatment difference in the primary efficacy variable between aliskiren/HCTZ and ramipril, assuming a standard deviation for $\mathrm{msSBP}$ of $13 \mathrm{~mm} \mathrm{Hg}$ with a two-sided significance level of $\mathrm{p}<0.05$.

The primary efficacy variable, change in msSBP from baseline in week 8 , was assessed with an ANCOVA model with baseline assessment as a covariate and treatment and patient randomization based on ABPM participation status at baseline as factors in the model. Mean differences, least-square mean 


\section{CardioRenal \\ Medicine}

\begin{tabular}{l|l}
\hline Cardiorenal Med 2011;1:53-66 \\
\hline $\begin{array}{l}\text { DOI: 10.1159/000322864 } \\
\text { Published online: January 17, } 2011\end{array}$ & $\begin{array}{l}\text { @ } 2011 \text { S. Karger AG, Basel } \\
\text { www.karger.com/crm }\end{array}$ \\
\hline
\end{tabular}

Whaley-Connell et al.: Renin Inhibition in Obese Hypertensives

differences, 95\% confidence intervals (CI), and $\mathrm{p}$ values for comparisons between the aliskiren/HCTZ combination and ramipril monotherapy were reported. Tests for the superiority of aliskiren/HCTZ versus ramipril were based on the null hypothesis of an equal mean change in msSBP in week 8 for aliskiren/ HCTZ and ramipril with a two-sided test at the $5 \%$ level of significance. All analyses were carried out for the intent-to-treat (ITT) population (consisting of all randomized patients who received at least one dose of the study medication and had at least one valid post-baseline assessment of the primary efficacy variable) using both last-observation-carried-forward and observed cases. The analyses of the secondary efficacy variable of change from baseline in $\mathrm{msDBP}$ were similar to the analyses of the primary efficacy variable. The secondary efficacy variable of percentage of patients achieving BP control ( $\mathrm{msSBP} / \mathrm{msDBP}$ $<140 / 90 \mathrm{~mm} \mathrm{Hg}$ ) was analyzed using the Cochran-Mantel-Haenszel test.

For the efficacy variables associated with 24-hour ABP measures and arterial compliance measures, the analysis was based on patients participating in the ABPM substudy. The primary analysis time point was week 8 and the analyses were performed using the same methods used to analyze the primary efficacy variable.

Spearman's correlation test was performed to evaluate the relationships among the three measures of BP assessment (clinical, ABPM and central BP). Both baseline and change from baseline in SBP between clinical and ABPM and between clinical and central measures were estimated. The metabolic measures and biomarkers were analyzed using non-parametric tests and log-transformed data. All statistical analyses were performed using SAS $^{\circledR}$ (version 8.2).

\section{Results}

\section{Study Population}

A total of 642 patients were screened, of whom 386 were randomly assigned to receive aliskiren/HCTZ $(\mathrm{n}=193)$ or ramipril $(\mathrm{n}=193$; fig. 2$)$. Of these, $340(88.1 \%)$ patients completed the 8 -week study. Forty-six patients (23 in each treatment group) withdrew from the study; the most common reasons for patient withdrawal were consent withdrawal (8 in the aliskiren/HCTZ group and 5 in the ramipril group); AEs (6 in the aliskiren/HCTZ group and 3 in the ramipril group); unsatisfactory therapeutic effect ( 8 in the ramipril group), and loss to follow-up (4 in the aliskiren/HCTZ group and 3 in the ramipril group). A total of 6 patients were excluded from the ITT population because they had no msSBP assessments after baseline. A total of 89 randomized patients participated in the ABPM substudy (45 in the aliskiren/HCTZ group and 44 in the ramipril group).

Demographic and baseline characteristics were well balanced between the two treatment groups (table 1). Overall, average age of the patients was 54.9 years, with most patients $(79.5 \%)$ being $<65$ years of age and predominantly white (63.0\%). Average BMI was 35.3 and more than two thirds of the patients (69.9\%) fulfilled the diagnostic criteria for the metabolic syndrome proposed by the National Cholesterol Education Program Adult Treatment Panel III [15]. The patients enrolled in the ABPM substudy had similar baseline characteristics as the overall population (average age: 56 years; $21 \%$ patients $>65$ years of age; $45 \%$ males, $\mathrm{n}=40$; average BMI: $35.8 ; 27 \%$ diabetics, $\mathrm{n}=24$ ). There were no differences between the two treatment groups. The mean clinical BP of patients in the overall study was $167.6 / 95.4 \mathrm{~mm}$ $\mathrm{Hg}$ and that for patients enrolled in the ABPM study was 169.2/94.8 mm Hg. Baseline maSBP and maDBP were 146.2 and $88.3 \mathrm{~mm} \mathrm{Hg}$, respectively.

\section{Changes in BP Measurements}

Clinical BP. At the 8-week endpoint, aliskiren added to HCTZ contributed to greater reductions in both msSBP and msDBP compared with ramipril monotherapy (fig. 3a, b). The reductions in msSBP and msDBP achieved with aliskiren/HCTZ were also substantially greater than those with ramipril alone in week 1 ( $p=0.0001$ for $\mathrm{msSBP}$ and $\mathrm{p}=0.02$ for $\mathrm{msDBP}$ ) and week 4 ( $\mathrm{p}<0.0001$ for both $\mathrm{msSBP}$ and msDBP; fig. $3 \mathrm{c}$ ). 


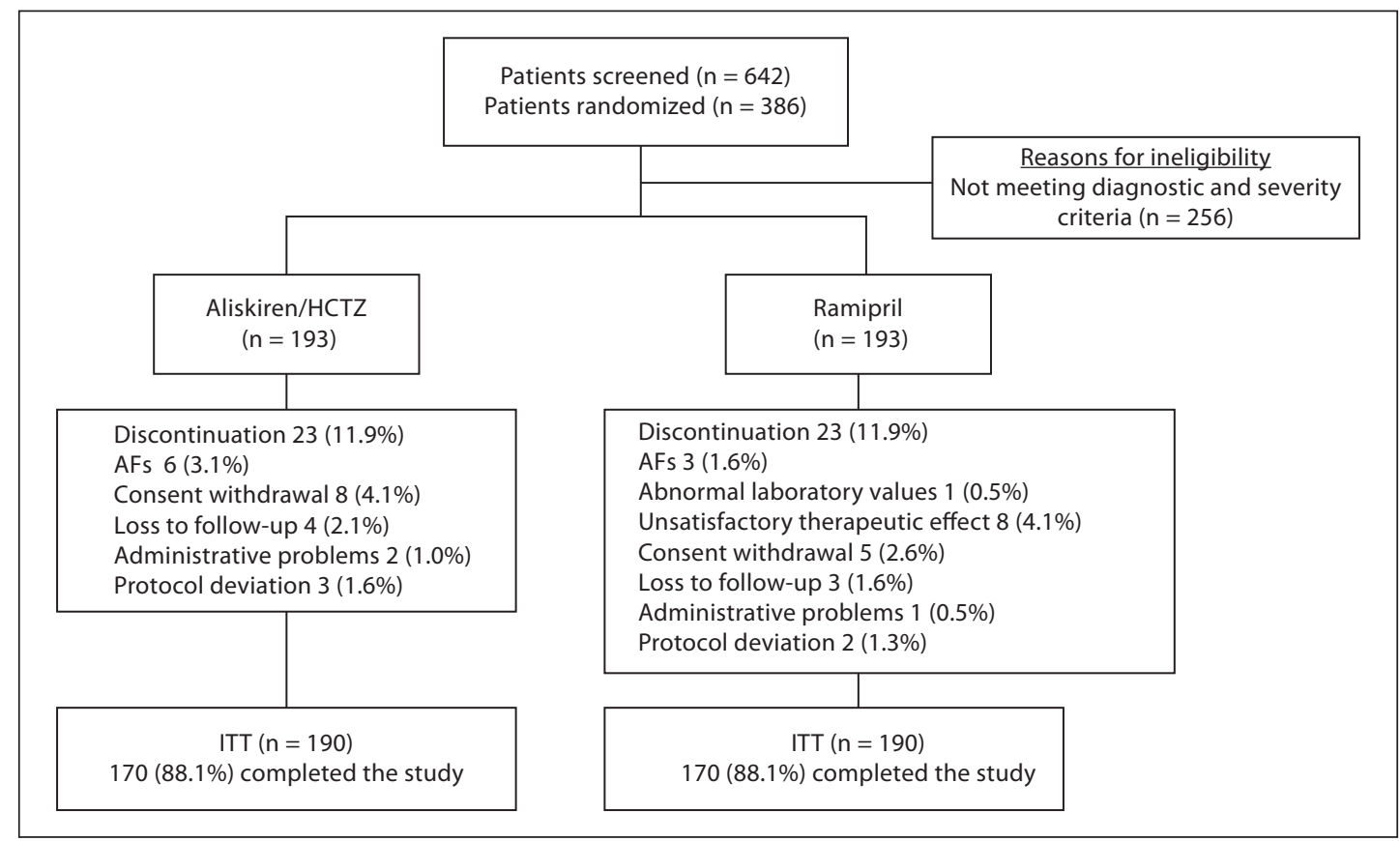

Fig. 2. Patient flow diagram. In the aliskiren/HCTZ group, AEs $(n=6)$ were deep vein thrombosis, fatigue, hypoesthesia, palpitation, blurred vision, and dehydration/pollakiuria ( $\mathrm{n}=1$, respectively). In the ramipril group, AEs $(\mathrm{n}=3)$ were peripheral edema, increased blood creatinine phosphokinase and convulsion ( $\mathrm{n}=1 / 0.5 \%$, respectively).

$A B P$ Measures. Baseline maSBP measures for the two treatment groups were approximately $20 \mathrm{~mm} \mathrm{Hg}$ lower than clinical msSBP. As with the clinical BP measures, at the 8-week endpoint, the reductions in both maSBP and maDBP versus baseline were significantly greater with aliskiren/HCTZ than with ramipril alone $(p=0.013$ for maSBP and $p=0.002$ for maDBP; fig. 4) in the subset of patients included in the ABPM analysis. The hourly ABP at the 8-week endpoint shows consistent reduction with the aliskiren/HCTZ combination compared with ramipril monotherapy (fig. 5).

Central BP. Consistent with the clinical BP measures and ambulatory measures, reductions in both central SBP and central DBP from baseline were significantly in favor of aliskiren/HCTZ ( $\mathrm{p}<0.05$; fig. 4$)$.

BP Control Rates. The percentage of patients achieving BP control $(<140 / 90 \mathrm{~mm} \mathrm{Hg})$ was significantly greater in the aliskiren/HCTZ treatment group than in the ramipril group at each visit. At the 8-week endpoint, 51.7\% (90/174) of the patients in the aliskiren/HCTZ group achieved BP control while only 20.2\% (35/173) achieved control with ramipril (between-treatment difference, 31.5; 95\% CI: 21.4-41.6; $\mathrm{p}<0.0001)$.

Correlation between the Three Measures of BP Assessment at Baseline. In the overall study, estimated Spearman correlation coefficients indicate significant correlations between the three methods of BP assessment. Correlation coefficients at baseline between clinical and ABP measures $(r=0.39 ; p=0.003)$ and between clinical and central BP measures $(r=0.60$; $p<0.001)$ were highly significant. Similar results were also obtained for the estimated Spearman correlation coefficients regarding change from baseline between clinical measures versus ABPM and between clinical versus central measures, with correlation coefficients between clinical and ABPM $(\mathrm{r}=0.44 ; \mathrm{p}=0.0005)$ and between clinical and central BP $(\mathrm{r}=0.68$; $\mathrm{p}<0.0001)$ being highly significant. 


\section{CardioRenal \\ Medicine}

\begin{tabular}{l|l}
\hline Cardiorenal Med 2011;1:53-66 \\
\hline $\begin{array}{l}\text { DOI: 10.1159/000322864 } \\
\text { Published online: January 17, } 2011\end{array}$ & $\begin{array}{l}\text { @ 2011 S. Karger AG, Basel } \\
\text { www.karger.com/crm }\end{array}$ \\
\hline
\end{tabular}

Table 1. Baseline characteristics of the study patients

\begin{tabular}{|c|c|c|c|}
\hline Characteristics & $\begin{array}{l}\text { Aliskiren/HCTZ } \\
(\mathrm{n}=193)\end{array}$ & $\begin{array}{l}\text { Ramipril } \\
(\mathrm{n}=193)\end{array}$ & $\mathrm{p}$ value \\
\hline Age, years & $55.4 \pm 11.2$ & $54.4 \pm 10.9$ & 0.38 \\
\hline \multicolumn{4}{|l|}{ Age group, n (\%) } \\
\hline$<65$ years & $150(77.7)$ & $157(81.3)$ & \\
\hline$\geq 65$ years & $43(22.3)$ & $36(18.7)$ & \\
\hline Gender, n (\%) & & & 0.41 \\
\hline Male & $86(44.6)$ & $94(48.7)$ & \\
\hline Female & $107(55.4)$ & $99(51.3)$ & \\
\hline Race, n (\%) & & & 0.33 \\
\hline Caucasian & $120(62.2)$ & $123(63.7)$ & \\
\hline Black & $60(31.1)$ & $64(33.2)$ & \\
\hline Asian & $2(1.0)$ & 0 & \\
\hline Other & $11(5.7)$ & $6(3.1)$ & \\
\hline Weight, kg & $101.1 \pm 18.4$ & $100.6 \pm 15.7$ & 0.79 \\
\hline BMI & $35.6 \pm 4.5$ & $35.1 \pm 4.3$ & 0.30 \\
\hline Metabolic syndrome, n (\%) & $138(71.5)$ & $132(68.4)$ & 0.45 \\
\hline Diabetes, n (\%) & $42(21.8)$ & $35(18.1)$ & 0.38 \\
\hline Prior medication ${ }^{1}, \mathrm{n}(\%)$ & $139(72)$ & $138(68.5)$ & \\
\hline ACEI & $44(22.8)$ & $47(24.4)$ & \\
\hline$\beta$-blocker & $25(13.0)$ & $20(10.4)$ & \\
\hline Dihydropyridine CCB & $20(10.4)$ & $21(10.9)$ & \\
\hline Thiazide diuretic & $32(16.6)$ & $28(14.5)$ & \\
\hline $\mathrm{ARB}$ & $28(14.5)$ & $34(17.6)$ & \\
\hline ACEI/diuretic combination & $3(1.6)$ & $2(1.0)$ & \\
\hline ARB/diuretic combination & $22(11.4)$ & $17(8.8)$ & \\
\hline ACEI/CCB combination & $4(2.1)$ & $8(4.1)$ & \\
\hline $\mathrm{msSBP}, \mathrm{mmHg}$ & $167.2 \pm 7.1$ & $168.2 \pm 7.8$ & 0.16 \\
\hline $\mathrm{msDBP}, \mathrm{mmHg}$ & $94.6 \pm 8.8$ & $96.2 \pm 8.5$ & 0.07 \\
\hline
\end{tabular}

Data are expressed as means (SD) unless stated otherwise. Metabolic syndrome was defined as 2 or more of the following symptoms: waist circumference $\geq 102 \mathrm{~cm}$ for men or $\geq 88 \mathrm{~cm}$ for women; triglycerides $\geq 150 \mathrm{mg} / \mathrm{dl}$; high-density lipoprotein cholesterol $<40 \mathrm{mg} / \mathrm{dl}$ for men or $<50 \mathrm{mg} / \mathrm{dl}$ for women, and fasting glucose $\geq 100$ and $<126 \mathrm{mg} / \mathrm{dl}$. Diabetes was defined as a clinical history of diabetes or treatment for diabetes. $\mathrm{CCB}=$ Calcium channel blocker.

${ }^{1}$ Within 30 days of randomization.

\section{Biomarkers}

PRA Levels. In randomly assigned patients, pretreatment geometric mean PRA was 0.64 $\mathrm{ng} / \mathrm{ml} / \mathrm{h}$ in the aliskiren/HCTZ group and $0.81 \mathrm{ng} / \mathrm{ml} / \mathrm{h}$ in the ramipril group. At study end, the aliskiren/HCTZ combination significantly reduced PRA by $45 \%$ (table 2). In contrast, ramipril led to a $88 \%$ increase in PRA. The aliskiren/HCTZ combination provided a greater increase in PRC from baseline (geometric mean increase, $816 \%$ ), as did ramipril (geometric mean increase, 91\%); however, the increases with aliskiren/HCTZ were significantly greater than with ramipril $(\mathrm{p}<0.0001)$.

Plasma Aldosterone. At study end, aliskiren/HCTZ increased plasma aldosterone levels by $17 \%$ versus baseline (table 2), whereas ramipril decreased plasma aldosterone levels by $3.4 \%$ versus baseline.

Urinary F2-Isoprostane/Creatinine Ratio. At study end, aliskiren/HCTZ decreased the urinary F2-isoprostane/creatinine ratio versus baseline (geometric mean $181.3 \mathrm{pmol} / \mathrm{mmol}$ at baseline vs. $145.9 \mathrm{pmol} / \mathrm{mmol}$ in week $8 ; 18.3 \%$ decrease), while ramipril caused a small 


\section{CardioRenal Medicine}

\begin{tabular}{l|l}
\hline Cardiorenal Med 2011;1:53-66 \\
\hline DOI: 10.1159/000322864 & $\begin{array}{l}\text { @ } 2011 \text { S. Karger AG, Basel } \\
\text { www.karger.com/crm }\end{array}$ \\
Published online: January 17, 2011 &
\end{tabular}

Whaley-Connell et al.: Renin Inhibition in Obese Hypertensives

Table 2. Biomarkers at baseline (week 0) and at the study end (week 8)

\begin{tabular}{|c|c|c|c|c|c|}
\hline \multirow[t]{2}{*}{ Biomarkers } & \multicolumn{2}{|c|}{ Aliskiren/HCTZ } & \multicolumn{2}{|l|}{ Ramipril } & \multirow{2}{*}{$\begin{array}{l}\text { Aliskiren/HCTZ } \\
\text { vs. ramipril } \\
\text { LS geometric mean } \\
\text { ratio }[95 \% \mathrm{CI}]\end{array}$} \\
\hline & baseline & study end & baseline & study end & \\
\hline \multirow{3}{*}{$\begin{array}{c}\text { Plasma renin concentration } \\
\text { Geometric mean, ng/l } \\
\text { Change vs. baseline, } \%\end{array}$} & $(\mathrm{n}=159)$ & $(\mathrm{n}=159)$ & $(\mathrm{n}=159)$ & $(\mathrm{n}=159)$ & \multirow[t]{3}{*}{$4.79[3.8,6.0]^{*}$} \\
\hline & \multirow[t]{2}{*}{$6.19 \pm 1.1$} & $53.49 \pm 1.3$ & \multirow[t]{2}{*}{$6.69 \pm 1.0$} & $12.08 \pm 1.2$ & \\
\hline & & +816 & & +91 & \\
\hline PRA & $(\mathrm{n}=161)$ & $(\mathrm{n}=159)$ & $(\mathrm{n}=161)$ & $(n=162)$ & \multirow[t]{3}{*}{$0.30[0.24,0.38]^{*}$} \\
\hline Geometric mean, ng/ml/h & \multirow[t]{2}{*}{$0.64 \pm 1.2$} & $0.35 \pm 1.1$ & \multirow[t]{2}{*}{$0.81 \pm 1.1$} & $1.37 \pm 1.2$ & \\
\hline Change vs. baseline, $\%$ & & -44.8 & & +83.3 & \\
\hline Plasma aldosterone & $(\mathrm{n}=160)$ & $(n=159)$ & $(\mathrm{n}=160)$ & $(\mathrm{n}=160)$ & \multirow[t]{3}{*}{$1.21[1.1,1.4]^{* *}$} \\
\hline Geometric mean, pmol/1 & \multirow[t]{2}{*}{$159.5 \pm 0.70$} & $187.3 \pm 0.76$ & \multirow{2}{*}{$165.2 \pm 0.76$} & $160.2 \pm 0.67$ & \\
\hline Change vs. baseline, $\%$ & & +17 & & -3.9 & \\
\hline Adiponectin & $(n=165)$ & $(\mathrm{n}=164)$ & $(\mathrm{n}=160)$ & $(n=160)$ & \multirow[t]{3}{*}{$0.96[0.89,1.02]$} \\
\hline Geometric mean, $\mu \mathrm{g} / \mathrm{ml}$ & \multirow[t]{2}{*}{$6.5 \pm 0.5$} & $6.5 \pm 0.5$ & \multirow[t]{2}{*}{$6.2 \pm 0.5$} & $6.5 \pm 0.5$ & \\
\hline Change vs. baseline, \% & & +2.2 & & +7.1 & \\
\hline UACR & $(\mathrm{n}=20)$ & $(n=19)$ & $(\mathrm{n}=28)$ & $(n=28)$ & \multirow[t]{3}{*}{$0.50[0.3,0.83]^{* *}$} \\
\hline Geometric mean, mg/mmol & \multirow[t]{2}{*}{$1.59 \pm 1.4$} & $0.90 \pm 1.02$ & \multirow[t]{2}{*}{$1.25 \pm 1.6$} & $1.84 \pm 1.6$ & \\
\hline Change vs. baseline, $\%$ & & -47.5 & & +4.75 & \\
\hline Urinary isoprostane/creatinine ratio & $(\mathrm{n}=138)$ & $(\mathrm{n}=139)$ & $(\mathrm{n}=161)$ & $(n=161)$ & \multirow[t]{3}{*}{$0.77[0.61,0.96]^{* * *}$} \\
\hline Geometric mean, pmol/mmol & $181.3 \pm 1.3$ & $145.9 \pm 1.3$ & $189.7 \pm 1.5$ & $197.7 \pm 1.6$ & \\
\hline Change vs. baseline, $\%$ & & -18.3 & & +6.6 & \\
\hline
\end{tabular}

Data are expressed as means \pm SD. UACR was measured only in the subset of patients included in the 24-hour ABPM study. ${ }^{*} \mathrm{p}<0.0001,{ }^{* *} \mathrm{p}<0.01,{ }^{* * *} \mathrm{p}<0.02$, aliskiren/HCTZ vs. ramipril. LS = Least square.

Table 3. AEs by treatment group

\begin{tabular}{lcc}
\hline AEs & $\begin{array}{l}\text { Aliskiren/HCTZ } \\
(\mathrm{n}=193)\end{array}$ & $\begin{array}{l}\text { Ramipril } \\
(\mathrm{n}=193)\end{array}$ \\
\hline Any AE, n (\%) & $69(35.8)$ & $72(37.3)$ \\
Discontinuation due to AE, n (\%) & $6(3.1)$ & $3(1.6)$ \\
Serious AE, n (\%) & $4(2.1)$ & $2(1.0)$ \\
Suspected treatment-related AE, n (\%) & $19(9.8)$ & $20(10.4)$ \\
Deaths, n (\%) & 0 & 0 \\
AEs in $\geq 2 \%$ of patients in any treatment group, $\mathrm{n}(\%)$ & $14(7.3)$ & $17(8.8)$ \\
Headache & $7(3.6)$ & $5(2.6)$ \\
Nasopharyngitis & $4(2.1)$ & $7(3.6)$ \\
Dizziness & $4(2.1)$ & $4(2.1)$ \\
Fatigue & $4(2.1)$ & $3(1.6)$ \\
Sinusitis & $4(2.1)$ & 0 \\
Frequent urination & $2(1.0)$ & $4(2.1)$ \\
Upper respiratory tract infection & $2(1.0)$ & $4(2.1)$ \\
Back pain & &
\end{tabular}

If a patient experienced more than one episode of a particular AE, the patient was counted only once for the event. 


\section{CardioRenal Medicine}

\begin{tabular}{l|l}
\hline Cardiorenal Med 2011;1:53-66 \\
\hline $\begin{array}{l}\text { DOI: 10.1159/000322864 } \\
\text { Published online: January 17, } 2011\end{array}$ & $\begin{array}{l}\text { @ 2011 S. Karger AG, Basel } \\
\text { www.karger.com/crm }\end{array}$ \\
\hline
\end{tabular}

Whaley-Connell et al.: Renin Inhibition in Obese Hypertensives
Fig. 3. Least square mean (LSM) changes versus baseline in $\mathrm{msSBP}$ (a) and msDBP (b) at the 8-week endpoint. ${ }^{*} \mathrm{p}<0.0001,{ }^{* *} \mathrm{p}<$ 0.05 , vs. ramipril. c Summary statistics for msSBP and msDBP throughout the double-blind period (ITT population). $\mathrm{n}$ is the number of ITT patients with both baseline and endpoint non-missing values (last-observation-carried-forward approach). Error bars denote SEM (from an analysis of covariance with baseline msSBP as a covariate and treatment at baseline as factors in the model).

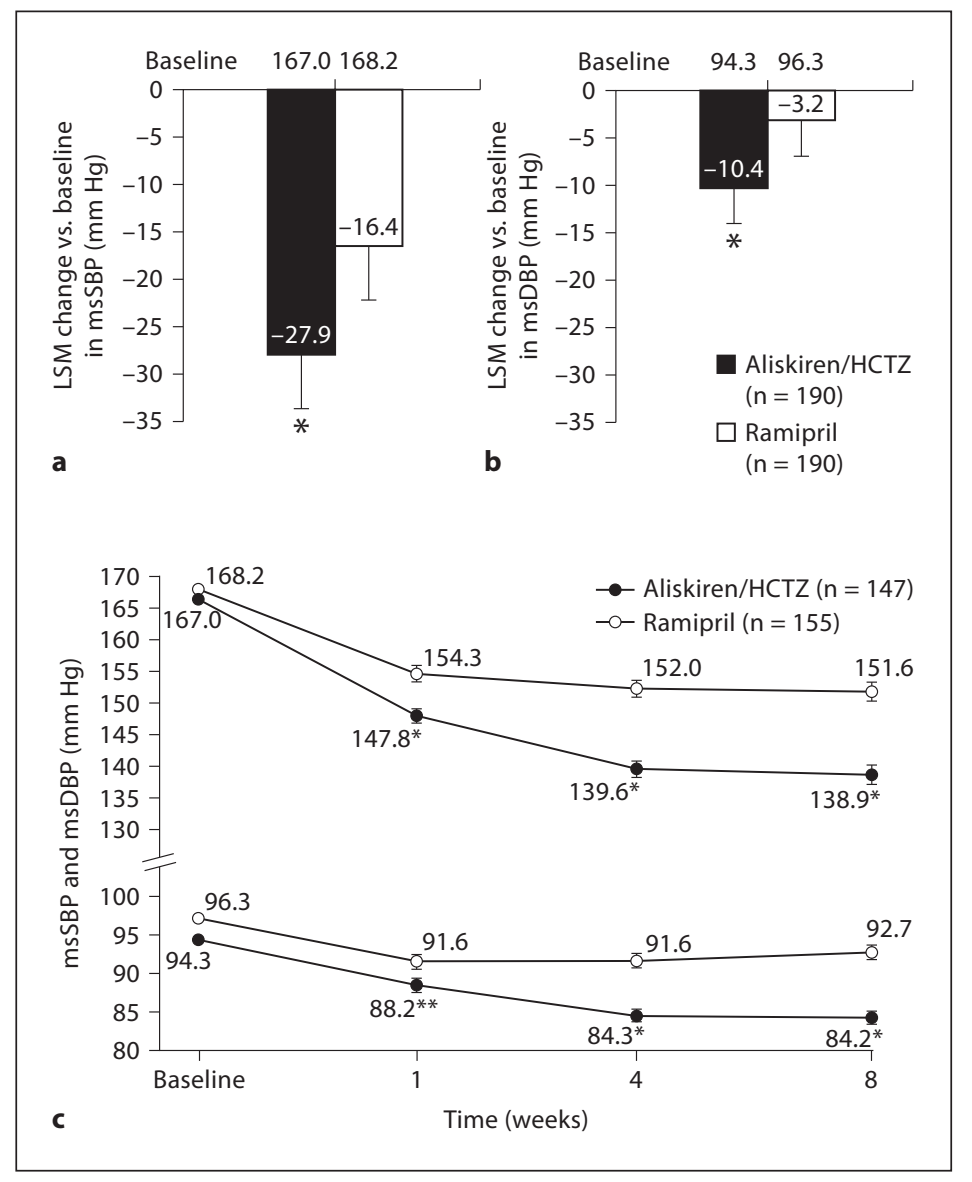

increase of $6.6 \%$ (geometric mean $189.8 \mathrm{pmol} / \mathrm{mmol}$ at baseline vs. $197.1 \mathrm{pmol} / \mathrm{mmol}$ in week $8 ; \mathrm{p}=0.018$, aliskiren/HCTZ vs. ramipril; table 2).

Other Biomarkers. Aliskiren/HCTZ decreased UACR by $48 \%$ (geometric mean $1.6 \mathrm{mg} /$ $\mathrm{mmol}$ at baseline vs. $0.90 \mathrm{mg} / \mathrm{mmol}$ in week 8 ), while ramipril increased UACR by $4.8 \%$ (geometric mean $1.3 \mathrm{mg} / \mathrm{mmol}$ at baseline to $1.84 \mathrm{mg} / \mathrm{mmol}$ in week 8 ).

\section{Adverse Events}

Overall, 35.8\% (69/193) of the patients in the aliskiren/HCTZ group and 37.3\% (72/193) in the ramipril group experienced at least one treatment-emergent $\mathrm{AE}$ that was mild to moderate in severity (table 3). The most common AE occurring in at least $5 \%$ of the patients was headache, with similar incidence rates in either group. The only suspected treatment-related AEs experienced by at least $2 \%$ of patients in either treatment group were headache (2.6 and $3.1 \%)$, pollakiuria (2.1 and 0\%), and dizziness (0.5 and 2.1\%) for aliskiren/HCTZ and ramipril, respectively.

Serious AEs were only experienced by 4 patients in the aliskiren/HCTZ group (including chest pain, deep vein thrombosis, pancreatitis, dehydration, and pollakiuria; defined as frequent daytime urination) and 2 patients (with hypertension and convulsion) in the ramipril group. The dehydration and pollakiuria reported with aliskiren/HCTZ occurred in the same patient and resulted in the patient's discontinuation of the study. The patients experiencing deep vein thrombosis with aliskiren/HCTZ and convulsion with ramipril also discontinued the study. Other AEs resulting in discontinuation were fatigue, palpita- 


\section{CardioRenal Medicine}

\begin{tabular}{l|l}
\hline Cardiorenal Med 2011;1:53-66 \\
\hline DOI: 10.1159/000322864 & $\begin{array}{l}\text { @ 2011 S. Karger AG, Basel } \\
\text { www.karger.com/crm }\end{array}$ \\
Published online: January 17, 2011 &
\end{tabular}

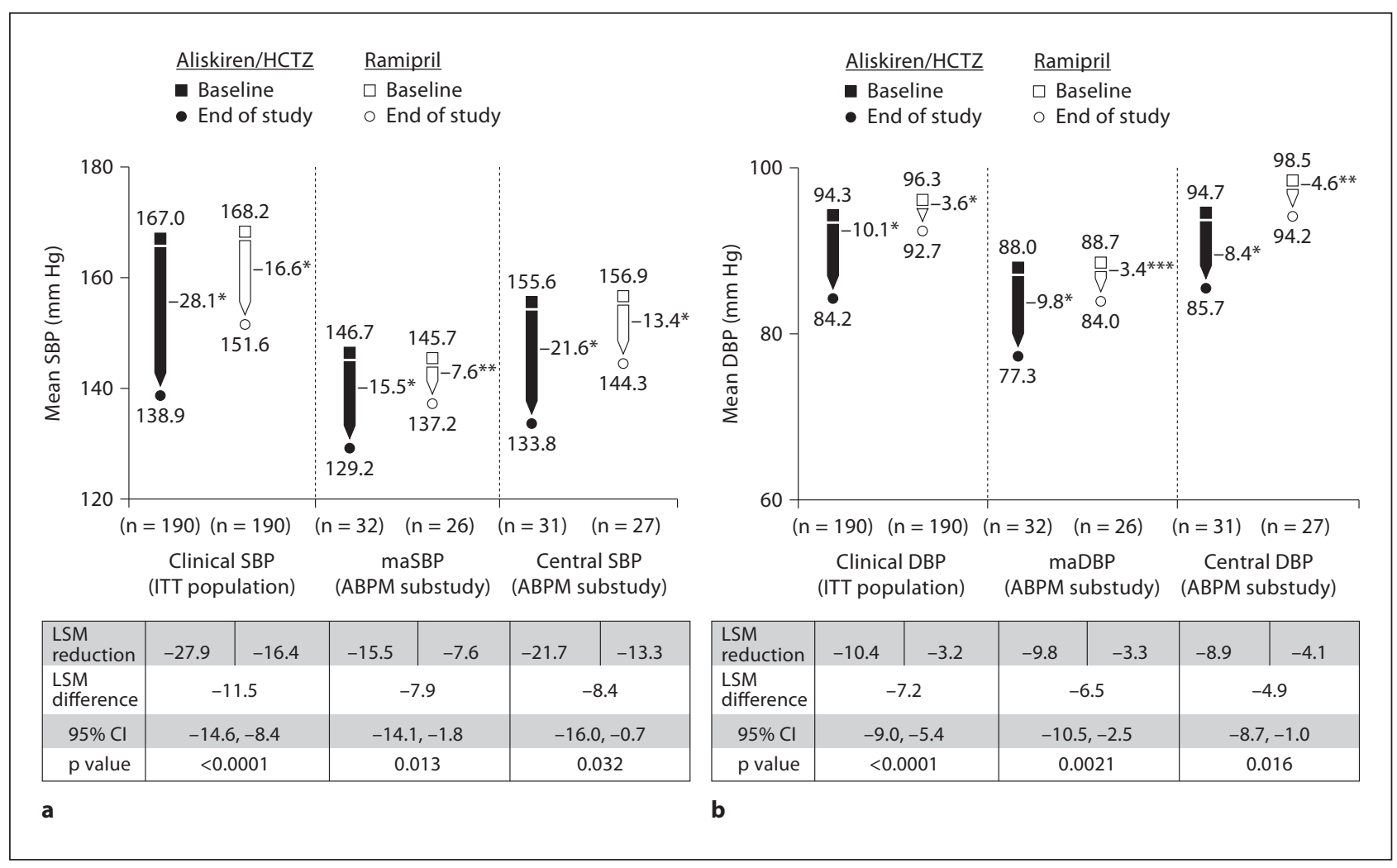

Fig. 4. Least square mean (LSM) changes versus baseline (week 0 ) in ambulatory and central SBP (a) and DBP (b) at the 8-week endpoint compared to clinical BP. ${ }^{*} \mathrm{p}<0.001,{ }^{* *} \mathrm{p}<0.01,{ }^{* *} \mathrm{p}<0.05$, vs. baseline.

tion, blurred vision, and gastrointestinal disorder with aliskiren/HCTZ, and peripheral edema and increased blood creatinine phosphokinase with ramipril. Thus, a total of 6 patients in the aliskiren/HCTZ group and 3 patients in the ramipril group discontinued the study.

\section{Discussion}

Results from this investigation support the notion that a combination of aliskiren with HCTZ produces greater reductions in BP than ramipril monotherapy in an obese, stage 2 hypertensive population. These data further indicate significant reductions in central SBP and DBP following aliskiren/HCTZ compared with ramipril treatment. This is the first study conducted in obese patients that included measures of central BP, ABPM, and markers of RAS activity and oxidative stress. Thus, a comparison of the present results with previously conducted studies is not possible. Nevertheless, BP reduction, whether measured in the clinic, by ABPM, or by central pressure determination, was consistently greater with the aliskiren/HCTZ combination compared to ramipril.

The finding that treatment reductions in central BP correlated strongly with clinical BP is particularly noteworthy in this population. The BP waveform is known to vary between the peripheral conduit (brachial) and the central elastic (aorta) arteries, with increases in SBP in patients with various co-morbid states, such as advanced age, cardiovascular disease, and 


\section{CardioRenal Medicine}

\begin{tabular}{l|l}
\hline \multicolumn{2}{l}{ Cardiorenal Med 2011;1:53-66 } \\
\hline $\begin{array}{l}\text { DOI: 10.1159/000322864 } \\
\text { Published online: January 17, } 2011\end{array}$ & $\begin{array}{l}\text { ( ) 2011 S. Karger AG, Basel } \\
\text { www.karger.com/crm }\end{array}$ \\
\hline
\end{tabular}

Whaley-Connell et al.: Renin Inhibition in Obese Hypertensives
Fig. 5. Hourly ambulatory 24hour SBP and DBP at the 8-week endpoint.

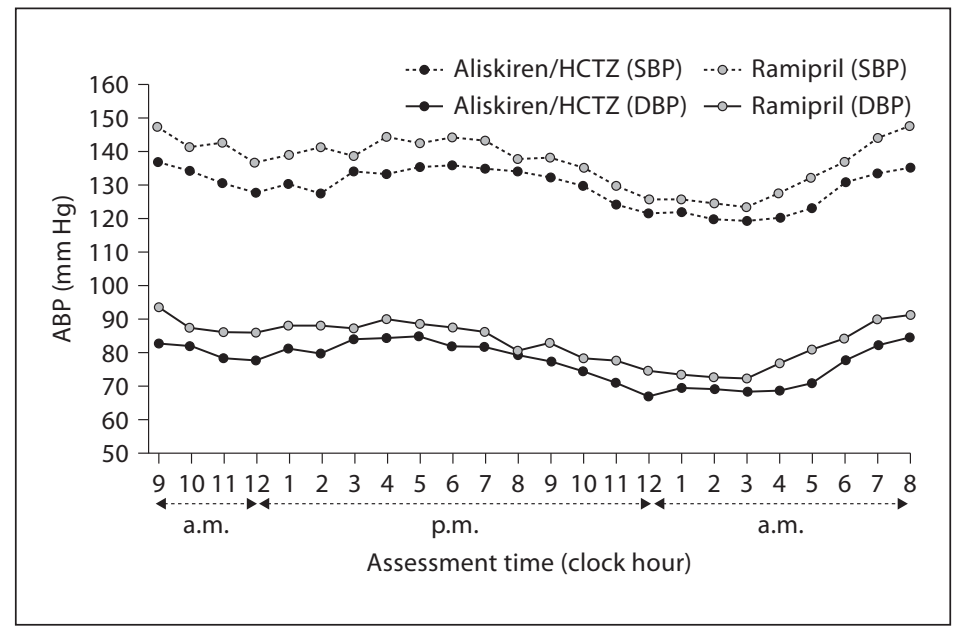

treatment with various antihypertensive or vasoactive agents $[14,16,17]$. The notion that antihypertensive drugs affect peripheral and central BP differentially is increasingly recognized with various cardiovascular risk reduction strategies. In this regard, RAS inhibitors have shown to have a greater efficacy in reducing central BP than peripheral measures compared to other classes of antihypertensive agents (e.g. calcium channel antagonists, $\beta$-blockers, and thiazide diuretics) [18-21]. The fact that reductions in central and peripheral measures were similar indicate that the population was largely a low-risk cardiovascular population, further suggesting that HCTZ added little benefit to the beneficial effects of aliskiren treatment on central pressure.

Increases in PRA have been associated with the development of hypertension in subjects with central obesity. Intervention with various RAS inhibitors contributes to a feedback increase in PRA, e.g. ACE inhibition with ACEI and ARBs, which is not observed with direct renin inhibition. Consistent with this notion, in our study aliskiren/HCTZ reduced PRA, while ramipril increased this measure, extending prior observations [10]. Furthermore, obesity and markers of insulin resistance are associated with a more active RAS and may contribute to enhanced oxidative stress, vascular remodeling and pressor responses [21, 22]. Both ACEI and ARBs have shown to reduce oxidative stress in preclinical models [23-26]. In this study, aliskiren/HCTZ reduced the urinary F2-isoprostane/creatinine ratio, a marker of oxidative stress, while ramipril induced a small increase. These data suggest a superior role for renin inhibition in the abrogation of RAS-mediated oxidative stress.

The results obtained with ramipril are consistent with another recent report [27]. In that exploratory study investigating the effect of $10 \mathrm{mg}$ of ramipril on vascular function, inflammation, and oxidative stress in patients with rheumatoid arthritis, the oxidative stress marker isoprostane was not reduced by ramipril [27]. This is especially important considering that ACEIs block Ang II production, and ARBs block its action via $\mathrm{AT}_{1} \mathrm{R}$ (Ang II type 1 receptor). Thus, both agents stimulate a reactive increase in PRC and PRA due to interruption of the negative feedback loop by which Ang II inhibits the release of renin from juxtaglomerular cells in the kidney [28]. This reactive rise in PRA may also limit the effectiveness of ACEIs and ARBs [29] compared with direct renin inhibition in attenuation of RAS-induced oxidative stress.

There are several limitations of this study. Since HCTZ was not included in the ramipril arm, improved efficacy of ramipril + HCTZ cannot be ruled out. Another limitation of this study was the small number of patients included in the ABPM and arterial compliance stud- 
ies. Studies in larger patient groups are needed to confirm the effects of aliskiren/HCTZ on central hemodynamics. Further, aliskiren/HCTZ increased plasma aldosterone in this study by $17 \%$. Although a HCTZ monotherapy treatment arm was not included in this study, elevation of aldosterone levels with HCTZ is a classic counterregulatory response with diuretics. While aliskiren as a monotherapy has not been shown to change plasma aldosterone levels [30, 31], it did reduce urinary aldosterone [31]. In conclusion, these data indicate that aliskiren/HCTZ reduced $\mathrm{BP}, \mathrm{PRA}$, and isoprostanes to a greater extent than did ramipril in obese patients with stage 2 hypertension. These data further support a strong correlation between clinical and central pressure determination wherein both aliskiren/ HCTZ and ramipril significantly reduced central SBP and DBP versus baseline in a prespecified subset of patients, with aliskiren/HCTZ having a greater effect than ramipril. The combination of aliskiren and HCTZ was well tolerated, and the results of this study suggest that aliskiren-based therapy is an effective and well-tolerated treatment option for obesityassociated hypertension.

\section{Summary Table}

What Is Known about the Topic

- Obesity-related hypertension is associated with enhanced RAS activity as well as impaired natriuresis, suggesting a therapeutic role for combination therapy with RAS blockers and diuretics.

- Aliskiren, a direct renin inhibitor, has been shown to decrease angiotensinogen, PRA, Ang II, and aldosterone levels, all of which are increased in obese individuals with hypertension.

- Direct renin inhibition with aliskiren is known to attenuate intrinsic as well as diuretic-induced RAS activation and associated increases in inflammation and oxidative stress.

\section{What This Study Adds}

- The study adds to our increasing recognition of the role for central pressure determination and its association with other measures in the determination of the optimal treatment strategies.

- Our results support the notion that a combination of aliskiren with HCTZ produces greater reductions in $\mathrm{BP}$ at dosing anticipated to be equivalent to ramipril monotherapy in obese individuals with stage 2 hypertension.

- Therapy with aliskiren/HCTZ reduced the urinary F2-isoprostane/creatinine ratio, a marker of oxidative stress, compared to the ACEI ramipril, indicating a superior role for renin inhibition in the abrogation of RAS-mediated oxidative stress.

\section{Acknowledgments}

The authors express their appreciation to Zena Ricks (Novartis Pharmaceuticals) for expert assistance in project management (ClinicalTrials.gov identifier: NCT00772577). The authors wish to thank Kanaka Sridharan (Novartis Pharmaceuticals) and Mike McNamara (Oxford Pharmagenesis, Inc.) for technical assistance and creation of figures.

\section{Disclosure Statement}

Das Purkayastha and Anthony Yadao are employees of Novartis Pharmaceuticals. This study was funded by Novartis Pharmaceuticals. 


\section{CardioRenal Medicine}

\begin{tabular}{l|l}
\hline Cardiorenal Med 2011;1:53-66 \\
\hline DOI: 10.1159/000322864 & $\begin{array}{l}\text { @ 2011 S. Karger AG, Basel } \\
\text { www.karger.com/crm }\end{array}$ \\
\hline Published online: January 17, 2011 &
\end{tabular}

Whaley-Connell et al.: Renin Inhibition in Obese Hypertensives

\section{References}

1 Ong KL, Cheung BM, Man YB, Lau CP, Lam KS: Prevalence, awareness, treatment, and control of hypertension among United States adults 1999-2004. Hypertension 2007;49:69-75.

-2 Poirier P, Giles TD, Bray GA, Hong Y, Stern JS, Pi-Sunyer FX, Eckel RH, American Heart Association, Obesity Committee of the Council on Nutrition, Physical Activity, and Metabolism: Obesity and cardiovascular disease: pathophysiology, evaluation, and effect of weight loss: an update of the 1997 American Heart Association Scientific Statement on Obesity and Heart Disease from the Obesity Committee of the Council on Nutrition, Physical Activity, and Metabolism. Circulation 2006;113:898-918.

-3 Bramlage P, Pittrow D, Wittchen HU, Kirch W, Boehler S, Lehnert H, Hoefler M, Unger T, Sharma AM: Hypertension in overweight and obese primary care patients is highly prevalent and poorly controlled. Am J Hypertens 2004;17: 904-910.

-4 Esler M, Straznicky N, Eikelis N, Masuo K, Lambert G, Lambert E: Mechanisms of sympathetic activation in obesityrelated hypertension. Hypertension 2006;48:787-796.

5 Hall JE: The kidney, hypertension, and obesity. Hypertension 2003;41:625-633.

6 Engeli S, Böhnke J, Gorzelniak K, Janke J, Schling P, Bader M, Luft FC, Sharma AM: Weight loss and the renin-angiotensin-aldosterone system. Hypertension 2005;45:356-362.

7 Wofford MR, Hall JE: Pathophysiology and treatment of obesity hypertension. Curr Pharm Des 2004;10:3621-3637.

-8 Ridker PM, Danielson E, Rifai N, Glynn RJ, Val-MARC Investigators: Valsartan, blood pressure reduction, and Creactive protein: primary report of the Val-MARC trial. Hypertension 2006;48:73-79.

9 Waeber B: Combination therapy with ACE inhibitors/angiotensin II receptor antagonists and diuretics in hypertension. Expert Rev Cardiovasc Ther 2003;1:43-50.

10 Jordan J, Engeli S, Boye SW, Le Breton S, Keefe DL: Direct renin inhibition with aliskiren in obese patients with arterial hypertension. Hypertension 2007;49:1047-1055.

11 Reisin E, Weir MR, Falkner B, Hutchinson HG, Anzalone DA, Tuck ML: Lisinopril versus hydrochlorothiazide in obese hypertensive patients: a multicenter placebo-controlled trial. Treatment in Obese Patients with Hypertension (TROPHY) Study Group. Hypertension 1997;30:140-145.

12 Morgan T, Lauri J, Bertram D, Anderson A: Effect of different antihypertensive drug classes on central aortic pressure. Am J Hypertens 2004;17:118-123.

13 Pickering TG, Hall JE, Appel LJ, Falkner BE, Graves J, Hill MN, Jones DW, Kurtz T, Sheps SG, Roccella EJ, Subcommittee of Professional and Public Education of the American Heart Association Council on High Blood Pressure Research: Recommendations for blood pressure measurement in humans and experimental animals: part 1: blood pressure measurement in humans: a statement for professionals from the Subcommittee of Professional and Public Education of the American Heart Association Council on High Blood Pressure Research. Hypertension 2005;45: $142-161$.

14 Williams B, Lacy PS, Thom SM, Cruickshank K, Stanton A, Collier D, Hughes AD, Thurston H, O’Rourke M, CAFE Investigators, Anglo-Scandinavian Cardiac Outcomes Trial Investigators, CAFE Steering Committee and Writing Committee: Differential impact of blood pressure-lowering drugs on central aortic pressure and clinical outcomes: principal results of the Conduit Artery Function Evaluation (CAFE) study. Circulation 2006;113:1213-1225.

15 Expert Panel on Detection, Evaluation, and treatment of high blood cholesterol in adults. Executive summary of the third report of the National Cholesterol Education Program (NCEP) expert panel on detection, evaluation, and treatment of high blood cholesterol in adults (Adult Treatment Panel III). JAMA 2001;285:2486-2497.

16 Avolio AP, Van Bortel LM, Boutouyrie P, Cockcroft JR, McEniery CM, Protogerou AD, Roman MJ, Safar ME, Segers P, Smulyan H: Role of pulse pressure amplification in arterial hypertension: experts' opinion and review of the data. Hypertension 2009;54:375-383.

-17 Agabiti-Rosei E, Mancia G, O’Rourke MF, Roman MJ, Safar ME, Smulyan H, Wang JG, Wilkinson IB, Williams B, Vlachopoulos C: Central blood pressure measurements and antihypertensive therapy: a consensus document. Hypertension 2007;50:154-160.

18 Koffi I, Lacolley P, Kirchengaast M, Pomiès JP, Laurent S, Benetos A: Prevention of arterial structural alterations with verapamil and trandolapril and consequences for mechanical properties in spontaneously hypertensive rats. Eur J Pharmacol 1998;361:51-60.

-19 Labat C, Lacolley P, Lajemi M, de Gasparo M, Safar ME, Benetos A: Effects of valsartan on mechanical properties of the carotid artery in spontaneously hypertensive rats under high-salt diet. Hypertension 2001;38:439-443.

20 Lacolley P, Labat C, Pujol A, Delcayre C, Benetos A, Safar M: Increased carotid wall elastic modulus and fibronectin in aldosterone-salt-treated rats: effects of eplerenone. Circulation 2002;106:2848-2853.

21 Dhakam Z, McEniery CM, Yasmin Cockcroft JR, Brown MJ, Wilkinson IB: Atenolol and eprosartan: differential effects on central blood pressure and aortic pulse wave velocity. Am J Hypertens 2006;19:214-219.

-22 Egan BM, Greene EL, Goodfriend TL: Insulin resistance and cardiovascular disease. Am J Hypertens 2001;14:116S$125 \mathrm{~S}$.

23 Romero JC, Reckelhoff JF: State-of-the-Art lecture. Role of angiotensin and oxidative stress in essential hypertension. Hypertension 1999;34:943-949.

24 Scribner AW, Loscalzo J, Napoli C: The effect of angiotensin-converting enzyme inhibition on endothelial function and oxidant stress. Eur J Pharmacol 2003;482:95-99. 
25 Whaley-Connell A, Govindarajan G, Habibi J, Hayden MR, Cooper SA, Wei Y, Ma L, Qazi M, Link D, Karuparthi PR, Stump C, Ferrario C, Sowers JR: Angiotensin II-mediated oxidative stress promotes myocardial tissue remodeling in the transgenic TG (mRen2) 27 Ren2 rat. Am J Physiol Endocrinol Metab 2007;293:E355-E363.

-26 Flammer AJ, Hermann F, Wiesli P, Schwegler B, Chenevard R, Hürlimann D, Sudano I, Gay S, Neidhart M, Riesen W, Ruschitzka F, Lüscher TF, Noll G, Lehmann R: Effect of losartan, compared with atenolol, on endothelial function and oxidative stress in patients with type 2 diabetes and hypertension. J Hypertens 2007;25:785-791.

27 Flammer AJ, Sudano I, Hermann F, Gay S, Forster A, Neidhart M, Künzler P, Enseleit F, Périat D, Hermann M, Nussberger J, Luscher TF, Corti R, Noll G, Ruschitzka F: Angiotensin-converting enzyme inhibition improves vascular function in rheumatoid arthritis. Circulation 2008;117:2262-2269.

28 Azizi M, Ménard J, Bissery A, Guyenne TT, Bura-Rivière A, Vaidyanathan S, Camisasca RP: Pharmacologic demonstration of the synergistic effects of a combination of the renin inhibitor aliskiren and the AT1 receptor antagonist valsartan on the angiotensin II-renin feedback interruption. J Am Soc Nephrol 2004;15:3126-3133.

29 Massiéra F, Bloch-Faure M, Ceiler D, Murakami K, Fukamizu A, Gasc JM, Quignard-Boulange A, Negrel R, Ailhaud G, Seydoux J, Meneton P, Teboul M: Adipose angiotensinogen is involved in adipose tissue growth and blood pressure regulation. FASEB J 2001;15:2727-2730.

30 Oparil S, Yarows SA, Patel S, Zhang J, Satlin A: Dual inhibition of the renin system by aliskiren and valsartan. Lancet 2007;370:1126-1127.

-31 McMurray JJ, Pitt B, Latini R, Maggioni AP, Solomon SD, Keefe DL, Ford J, Verma A, Lewsey J, Aliskiren Observation of Heart Failure Treatment (ALOFT) Investigators: Effect of the oral direct renin inhibitor aliskiren in patients with symptomatic heart failure. Circ Heart Fail 2008;1:17-24. 